\title{
THE ROASTED COCK CROWS: APOCRYPHAL WRITINGS (ACTS OF PETER, THE ETHIOPIC BOOK OF THE COCK, COPTIC FRAGMENTS, THE GOSPEL OF NICODEMUS) AND FOLKLORE TEXTS*
}

\author{
Ilona Nagy
}

\begin{abstract}
A miracle story of apocryphal origin (supposedly the Act of Peter), transformed into a plot with a typical paradoxical element, became popular in the oriental Christianity and in medieval Europe: this is how it got into the apocryphal New Testament narratives; among others into the newly discovered Ethiopian Book of the Cock, some early Coptic fragments and the medieval manuscripts of the Gospel of Nicodemus as well. The purpose of the present study is to document this unusual process (a story from an apocryphal source is transformed during traditional transmission, and finds its way into some versions of other apocryphal texts). The data attesting to the presence of the characteristic motif in orality are especially valuable. Conscious fieldwork and records from the 19th and 20th century reveal the oral variations, which take the form of an origin legend, aiming at an explanation of the world.
\end{abstract}

Key words: apocryphal gospels, Acta Petri, Acta Pilati, Evangelium Nicodemi, Ethiopic Book of the Cock, Coptic apycrypha, roasted cock crows, Judas legends

$$
\begin{aligned}
& \text { It happened on the day of the Holy Supper, that } \\
& \text { Lord Christ was served a roast cock, and when } \\
& \text { Judas left to sell the Lord, he ordered the cock } \\
& \text { to rise and follow Judas, and the cock did ac- } \\
& \text { cordingly, then reported to Lord Christ how } \\
& \text { Judas betrayed him, and because of this it is } \\
& \text { said to be allowed to follow him to Paradise. }
\end{aligned}
$$

Certain stories of apocryphal gospels have been present in the history of universal culture for nearly two thousand years. The texts of these gospels, which survived in various manuscripts, compose diverse variational sequences even in comparison with each other. In literary representations they appear again and again in later centuries as well, then in the 19th and 20th century we come across their variations also in oral folk tradition; in fortunate cases even 
in forms representing the characteristics of several peoples and cultures. The study of the folklore texts that have some written precedents helps to get better acquainted with the creation processes of folklore.

The legends that survived in oral tradition can be traced back to the kind of apocryphal gospels which can be considered folkloristic themselves. The process of supplementation is typical of these kinds of gospels, which means that their authors supplemented the canonical gospels with stories relating Jesus' and his parents' or other characters' life. The bulk of this type consists of the childhood-gospels and the Acts of Pilate (Acta Pilati, AP), which later became known as the Gospel of Nicodemus (Evangelium Nicodemi, EN). The unknown authors of these works obviously aimed to satisfy the curiosity of simple Christian people: they deal with the events of Jesus', Virgin Mary's, Joseph's and other characters' life, which are not at all or only briefly mentioned in the canonical gospels (Hennecke \& Schneemelcher 1959: 48-51). These authors found colorful and imaginative stories for their work in contemporary oral tradition rather than in the canonical gospels. After the texts became recorded in writing, they continued to live in innumerable manuscript versions, and were supplemented with further folklore texts, as it can be proved in the case of the Judas story, the subject of the present study. A miracle story of apocryphal origin (the Act of Peter), transformed into a plot with a typical paradoxical element, became popular in the oriental Christianity and in medieval Europe: this is how it got into the apocryphal New Testament narratives; among others into the Ethiopian Book of the Cock, some early Coptic fragments and the medieval manuscripts of the Gospel of Nicodemus as well. The purpose of the present study is to document this unusual process (a story from an apocryphal source is transformed during traditional transmission, and finds its way into some versions of other apocryphal texts). The data attesting to the presence of the characteristic motif in orality are especially valuable. Conscious fieldwork and records from the 19th and 20th century reveal the oral variations, which take the form of an origin legend, aiming at an explanation of the world.

\section{THE GOSPEL OF NICODEMUS}

The work entitled Accounts of Our Lord, Jesus Christ, Made in the Time of Pontius Pilate, commonly known as the Gospel of Nicodemus, originates from the beginning of the 5th century. It had some precedents, since in about the middle of the 2nd century, the apologist Justin refers to the act of Pilate, which was kept in the imperial archives (Apology 35; 48); and at the end of the century Tertullian refers to a report about Jesus, sent by Pilate to Emperor Tiber- 
ius (Apologeticum 21, 24). Eusebius has knowledge of pagan, anti-Christian acts of Pilate, which were produced in the time of Maximinus, persecutor of Christians, and the emperor ordered them to be read and known by heart at schools (Historia Ecclesiastica 1.9.3, 1.11.9, 9.5.1, 9.7.1). However, the nature of these precedents and their identity with the abovementioned work cannot be assessed (Scheidweiler 1990: 395; Adamik 1996b: 189-190). There is no patristic proof of the existence of the Gospel of Nicodemus before the 6th century (Gregory of Tours Decem libris historiarum 1.21), so the time of origin of the work was determined on the basis of the fragment of a 5th-century palimpsest from Vienna (Österreichische Nationalbibliothek MS 563; Izydorczyk 1997: 44-45). This manuscript was translated from Greek (the Greek "A" version) into Latin, and it constituted the basis of the subsequent rich Latin tradition.

The Evangelium Nicodemi has the following structure:

1. The conviction, crucifixion, resurrection and ascension of Jesus (chapters 1-11),

2. Authentic accounts of resurrected Jesus by the witnesses of the Resurrection: Joseph of Arimathea, Nicodemus and other witnesses (chapters 12$16)$, and

3. Jesus descends to the underworld.

The part containing the descension to Hell is a complete individual work in itself: it originates from the 2nd century, and it was attached to the previous parts only in the 5th century. It was included neither in the original Greek "A" version, nor in the later Eastern recensions which were translated from the Vienna palimpsest. The work can be found in codices under the titles Acta Pilati, Gesta Pilati; the title Evangelium Nicodemi appears only in the 13th century. The part containing the Descensus, the descension to Hell became particularly popular during the European Middle Ages, since these particulars are rarely included in canonical references (Ps. 23,7; Hos. 13,14; Acts 2,24; Rom. 7; Eph. 6; Rev. 1,18). It inspired mystery plays and dramas; for instance, in England it became especially significant because of its connection to the Grail legend and Joseph of Arimathea. ${ }^{1}$

Just like other apocryphal gospels, this work circulated in hundreds of manuscripts in the entire Christian world. After the emergence of the printing press, the publishers of the printed texts tried to clear up this complicated mess. They published the Latin text first in 1473; the 1555 edition by J.B. Herold and the 1703 one by Fabricius (to be discussed in more detail in this paper) became important for the later commentaries. The 1804 enlarged version of the latter, made by A. Birch, was the first modern edition of the Greek text of the Gospel of Nicodemus. The 1832 edition by Thilo, which gives Latin and Greek texts as well, contains extensive text commentaries that have not been surpassed up 
to now. The authoritative work, however, which still serves as a basis for translations as well as research, comes from Tischendorf (1876). It includes the texts listed here: The Greek "A" version: Hypomnémata tu kyriu hémón Iésu Christu prachthenta Pontiu Pilatu-Accounts of Our Lord, Jesus Christ, Made in the Time of Pontius Pilate - (cap. I-XVI, 210-286).

The Greek "B" version, in fact a revision of "A": Diégésis peri tu Plathus tu kyriu hémón Iésu Christu kai tés hagias autu Anastaseós - Accounts of the Descension of our Lord Jesus Christ and His Holy Resurrection (cap. I-XI, I XVII-XXVII/, 287-332). The Latin version, the Gesta Pilati - Acts of Pilate (cap. I-XVI, 333-388) comes next, then the Evangelium Nicodemi, Pars Altera sive Descensus Christi ad Inferos - The Gospel of Nicodemus, Second Part, Or the Descension of Christ to Hell (cap. I-XI, 389-432). These are followed by works attached to $E N$ as satellites, called "appendices" in scholarly literature: Epistola Pontii Pilati quam scribit ad Romanum Imperatorem de Domino Nostro Iesu Christo - Letters By Pontius Pilate, Written to the Roman Emperor about Our Lord Jesus Christ (433-434), Anaphora Pilatu - Pilate's Report (435-442) in Greek again, then the same in Latin, with Tiberius' reply, and more texts with similar themes. Tischendorf was the first to differentiate between the two Latin forms of the Descensus and the two Greek - "A" and "B" - recensions. The Greek "A" recension survived in 15 manuscripts; the oldest one is from the 12th century. As it has already been mentioned, none of these includes the Descensus, which supposedly did not originally belong to the apocryphon. All of the Latin and Oriental translations come from this "A" version of the Greek Acts of Pilate. The " $\mathrm{B}$ " recension survived in 30 codices; the oldest one is from the 14th century. It is stated in its prologue that the work was written by Annas (Ananias) in Hebrew, and translated by Nicodemus into Greek. Its content is similar to that of the "A" version, but the emphasis is different: for example, Pilate is more definitely presented here as a Christian figure; or the character of Virgin Mary is treated with special significance. Similarly to the Latin "A" version, it contains the episode of the descension to Hell. It probably emerged as a thorough revision of the original Greek text, motivated by liturgical purposes: chapters 1-12.2 were among the readings of Good Friday homilaries, chapters 12.3-17 of the Easter Sunday ones. Unlike the Greek "A", the Greek "B" version has never been translated to any other languages (Izydorczyk \& Dubois 1997: 27-29).

The authority of canonical texts was scrupulously guarded by the attentive church, nevertheless a whole lot of different interpretations emerged; so it is no wonder that the copying of apocryphal texts, under less supervision, among less rigorous circumstances, resulted in an incredible abundance of variations (extensions, omissions, etc.). In the continuous process of revision, the Latin 
manuscripts of the $E N$ retained only an abstract of the original apocryphal texts. "What remained were only their allo-texts, transformed and sometimes on the verge of losing their original identity," as Z. Izydorczyk wrote (1997: 44). Leaving aside the survey of text transmission since the Early Middle Ages, and the overview of the prose and verse treatments, let us now mention only two well-known and extremely popular works. The compilation Speculum Historiae by Vincent de Beauvais discusses the history of mankind from the creation to 1254, with the episodes of Christ's Passion, Descension to Hell, and Resurrection taken from the Gospel of Nicodemus. It emerged before 1260. The Legenda Aurea was written before 1267 by Jacobus de Voragine; it was perhaps the most influential hagiographic work of the Middle Ages. Its author, just like Beauvais, makes use of the apocryphal narratives liberally: he cites chapters from the Gospel of Nicodemus many times and in many ways. Hundreds or even thousands of manuscripts of both works circulated in Europe. In fact, they can be considered the secondary sources of the $E N$, but a lot of people got acquainted with the apocryphon mainly from these works: for example Pilate, depicted as an enemy, a wrong-doer. For Pilate was blamed for Christ's death in the Latin versions, unlike in the Greek ones, where Pilate was depicted as a Christian, or at least sympathizing with Christians (Uo. 74).

So the tradition and variation processes of the set of manuscripts known as the Gospel of Nicodemus were based on the Greek originals, mentioned above. Similarly to other apocryphal gospels, they became known in the entire Christian world due to the later Latin, Coptic, Syriac, Armenian, Georgian translations, and the medieval translations into European national languages. The publications on this text tradition are surveyed by Scheidweiler; the more recent ones can be found in Geerard's Clavis (Scheidweiler 1990; Geerard 1992). ${ }^{2}$

Even the latter became outdated quickly, which fact indicates that the recent years witnessed an astounding revival of the research of the apocrypha. Already in 1997, a volume of studies was published on the appearance of the $E N$ and its influence on medieval Western (Latin, French, Catalan,Occitanian, Italian, Old and Middle English, Norwegian, High German, Dutch, Low German, Irish, Welsh) literature, with an individual analysis of each (Izydorczyk 1997). The connoted bibliography of the volume (Gounelle \& Izydorczyk 1997) presents the text tradition of the AP: the publications and translations of the manuscripts, their commentaries by language (Greek, Latin; Oriental; medieval Western; Modern - since 1600 - translations from Greek, Latin or other languages), then it contains bibliographies, related literature and iconographic works. According to the authors, the selected polyglot bibliographies, encyclopaedias, etc. of the 1st and 2nd chapters "may reveal to the careful reader the evolution of popular, 'vulgate' notions about the apocryphon from the eight- 
eenth to the late twentieth century" (Gounelle \& Izydorczyk 1997: 421). Judging by the titles, however, the listed works do not inform about the appearance of the stories of the $A P$ in popular literature or folklore: actually it was not aimed at all. It means that the joint employing of the results of the classics and the folkloristics can be mutually advantageous. Folklore data from the 19th and the late 20th century, among them the different Slavonic and Hungarian texts published in this study can be appreciated in any case. The bibliography has no knowledge of any Hungarian work that deals with this apocryphon, namely with its Hungarian reception, since in fact it does not even exist, and the translation of Tischendorf's Greek "A" version by Tamás Adamik was published just in the previous year (Adamik 1996b).

The Gounelle-Izydorczyk bibliography gives an overview of the Slavic literature as well, but by no means is it intended to be exhaustive. According to the Santos-Otero manuscript catalogue, 184 Slavic manuscripts (including the Romanian ones as well) of the $E N$ survived. Unlike other apocrypha, these were translated from Latin earlier than from Greek. The Acts of Pilate, the AP provides the core of the Slavic $E N$. It has a longer redaction and a shorter one: the former can be traced back to a 10th-century complete Latin manuscript which contains the Descensus, and which was probably translated during the Old Church Slavonic period, in the 10th-11th century, presumably in Slovenia or Croatia. The shorter and later redaction, which contains only the first 16 chapters of the $E N$, was probably based on a Greek original; its earliest manuscript comes from the 13 th century. This one has the most versions, since similarly to the Greek "B" recension - it got into the Holy Week's liturgy to be read aloud. In Russia it was replaced by other passion stories coming from the West, especially Poland, only from the 16th century onwards (Santos Otero 1981: 61-64).

Since the reception of the $E N$ has not been worked up yet, only occasional data can be mentioned to support the opinion that there is no reason to think that this very apocryphal gospel failed to become part of medieval Hungarian culture. The stories of the Legenda Aurea - in the sermons of Pelbárt Temesvári (Pelbartus de Temeswar), and in the codices of those following and quoting him in Hungarian - imported the apocryphal tradition, which was also introduced to common people by way of later sermons, liturgical events and school dramas (including passion plays). Probably this is what happened, among others, to the narratives of The Gospel of Nicodemus as well. The work itself is mentioned in the collection of sermons entitled Sermones Dominicales, written by Dénes Mohácsi, canon of Pécs and archdeacon of Tolna, in 1456. Out of its 123 sermons 45 are borrowed from the Sermones Dominicales by Jacobus 
de Voragine, also the passage to be quoted here, though according to Áron Sziládyit is "extended" (Szilády 1910: passim and XIV):

Secondly, I'll ask about this passage: A re you E lija h? I wonder why the Jews didn't know that John was Zachary's son? I'll tell you why they didn't know: because, as it is written in the Gospel of Nicodemus, when he was a little child, his mother took John to the desert because of the tyrant Herod who ordered all boys to be murdered in Bethlehem and its environs; and he was nourished in that desert, that's why the Jews forgot about him. ${ }^{3}$

The chapter entitled "Hwfwetnak zentfeges ynepero ${ }^{\mathrm{e}}$ l ualo predicacio" of The Codex of Érsekújuár (Volf (1888: 87-104) was copied by the Dominican Márta Sövényházi. Her sources are varied:
Apart from Pelbárt, the shortened version of Vincentius Ferrarius' Christ- mas sermon is included in it, as well as the apocryphal Gospel of Nicodemus in the Easter sermon. [---] Although this [the Easter sermon mentioned above, I. N.] overlaps in a lot of points with chapters XIV- $X X V I$ of the apocryphal gospel, obviously it was not the direct source, or at least not the text published by Tischendorf under the titles Gesta Pilati and Descensus Christi ad Inferos. Since there are lengthy Latin texts in the sermon - whose genre can hardly be characterized as sermon -, and these are not identical with the published text, this section awaits a more precise exploration of sources as well.

And to make the situation even more complicated: "The end of the sermon is totally independent of the Descensus; it describes the meeting of resurrected Christ with the Virgin Mary and Mary Magdalene" (both quotations from Madas 1989: 209-210).

\section{THE COCK MIRACLE}

\subsection{The story of Judas in the apocrypha}

The subject of our study, the cock miracle, presented in the form of a Judas narrative, does not belong to the Greek "A" version, which can be considered the base text; so obviously it appears neither in its Latin translation nor in the further translations of the latter. Surprisingly it occurs just in the Greek "B" version, which - as we have already pointed out - has never been trans- lated 
into any other languages, and although it survived in 30 codices - accord- ing to my best knowledge, as far as it can be inferred from the literature - it is included in only two of these. Nevertheless, since in the folkloristic literature the cock miracle is considered to be of apocryphal origin, and it is linked to the Gospel of Nicodemus, it was necessary to summarize above whatever modern research has found out about this work, and whether it can be supposed from this that the Judas narratives containing the cock miracle originate from it. The connection of the cock miracle to the traditions about Judas is attested by a fairly early folklore item, and just among the notes of an early and rather significant publication of the apocryphal gospels. In his anthology of apocryphal New Testament gospels, published first in 1703, secondly in 1719 in Hamburg, Johann Albert Fabricius collected the references to the works that he published, and quoted these references in chronological order from the Fathers of the Church until his own time. Years ago I read the Arab childhood gospel there, and among the related "testimonies" I came across a reference to Melchisedech Nicolaus Thevenotus. Melchisedec Thévenot (1620-1692), a French traveller, wrote accounts of his journeys in Europe and the Orient ( Le grande encyclopédie (31: 8). ${ }^{4}$ His data consist of folklore narrations performed orally by Copts in the 17th century. In his Latin work, Fabricius gives the original French text either in German translation or abstracted in German. In Thévenot's itinerary - writes Fabricius - the following can be read of the Copts:

A lot of things originate from apocryphal books, which are still in use here. We do not know anything about how our Redeemer lived in his childhood, only they know about countless particular events concerning this period; and they say that every day an angel visited him from Heaven and gave him food, / and that / he created little birds from earth to pass the time, / then he blew at them, / threw them up in the air and made them fly. ${ }^{5}$

Then he goes on:

It happened on the day of the Holy Supper that Lord Christ was served a roast cock, and when Judas left to sell the Lord, he ordered the cock to rise and follow Judas, and the cock did accordingly, then reported to Lord Christ how Judas betrayed him, and because of this it is said to be allowed to follow him to Paradise. ${ }^{6}$

The peculiarity of the story fascinates the reader. Jesus knew his fate awaiting him: so why did he need to revive the roasted cock and make him spy on Judas? The Jesus-figure of the apocryphal gospels, especially the so-called Gospel 
of Thomas, usually bears the characteristics of the docetist tendency - that is, his human nature is only an illusion, and he has been capable of performing miracles since the moment of his birth (Nagy 2001: 53). But here we find that although he possesses divine power and can work miracles, his fallible human nature controls his deeds. Perhaps he hopes to avoid his fate. He wants proof of something he knows is bound to happen, and he wishes for confirmation. $\mathrm{He}$ could not ask the apostles or other humans to play this spying role, only a dumb animal, which is above suspicion and whose departure cannot strike the eye of anyone. This is why he performs the miracle, which supposedly did not have, and could not have, any eyewitnesses. So his purpose in working the miracle is by no means to gain recognition of his divine nature, as in the childhood stories (Nagy 2001: 49-70). In contrast with the docetist nature of the original texts, the late revisions of the apocrypha aimed to prove Jesus's human development (Cullmann 1959: 292, 300). Therefore the source of our text must have been a later, extended apocryphon. Thévenot also writes that the Copts know about some events of the Redeemer's life, which he, as a learned Christian, does not, and they get this knowledge from apocryphal books. But which apocryphal book contains the above narration? Fabricius gives this data among the "testimonies" of the Arab childhood-gospels, as an addition to the reference of the "Little Jesus's birds" type of narrative (in which the lifeless material, the mud comes to life and turns into a bird), since in the main text he gave the original source of that. In the Latin text of the $E N$, which he published in the same place, he could not possibly find its equivalent, so he could not suspect that it belonged there. In the folkloristic literature, R. Köhler was the first to mention Thévenot's Coptic data, though of course he referred to its original source; and this considerably diminished the satisfaction which the writer of the present study got from finding Fabricius' data (Köhler 1900: 641). So Thévenot's reference to the cock miracle became known in folkloristics not from Fabricius's work (since it is not known at all, even in the extended new philological literature as well) but from R. Köhler: this is a source from which it was transferred to Paul Lehman's Judas monography (Lehmann (1929: 346), then to L. Kretzenbacher's studies (1972: 435-446) Enzyklopädie des Märchens by E. Wimmer (1978: 684-688). Köhler specified two editions of the $E N$ as his source. One of them is Thilo's work (1823: CXXIX) the other one is that of Tischendorf. In the 3rd subheading of the 4th footnote attached to Chapter 4 of the Greek "B" version of the AP, Tischendorf inserted the supplement that was found in the 15th-century manuscripts from Paris and Venice that he called "B" and "C"10. For Tischendorf cited the "B" version from three ("A", "B", and "C") codices, now (Gounelle 2003: 36; Piovanelli 2003a: $438-440)$ quoted as $\mathrm{B}^{3}$ and $\mathrm{B}^{2}$ : 
Ilona Nagy

This is how the " $B$ " manuscript goes; and the " $C$ ", ignoring everything that we have copied out of the " $A$ " and " $B$ " manuscripts in chapter four here, starts with the following... (Tischendorf 1876: 289). "And so Judas went home to get a rope for the hanging, and he found his wife roasting a cock on embers. Instead of getting down to it [the cock], he told her: 'Stand up, woman, and give me a rope because I want to hang myself' (This part can not be found in "B"). His wife then told him: "Why do you say so?' And Judas says: 'I want you to know that I betrayed my master, Jesus, to the villains really unjustly so that Pilate will put him to death. But he [Jesus] will resurrect on the third day, and then woe betide us!' Then the woman tells him: Don't you say this or even think of it, because Jesus will resurrect as you say only if this cock roasted on embers is able to give sound'. As soon as she uttered these words, the cock spread its wings, and screams three times. Now Judas got even more astounded, and immediately tied a knot on the rope, hanged himself, and breathed his last. (Tischendorf 1876: 290)

\section{2. A 'newly discovered' apocryphal gospel ${ }^{11}$ : The Ethiopic Book of the Cock}

Until the last years concerning the motive of cock miracle only the sources mentioned above have circulated in scholarly literature. Now, thanks to the great efforts in philological investigations on apocryphal text tradition, folklorists can be in a more favorable situation.

Although a fragment of the Book of the Cock has long been known to Western scholars, and the entire work enjoys a privileged place in the liturgy of the Ethiopian church, the antiquity of the traditions that it preserves has not been recognized; hence the claim to have "newly discovered" an apocryphal text, the origins of which lie in the fifth or sixth century CE (Piovanelli 2003a:428, and in the abstract, sent by e-mail to the author from Cambridge University Press).

In this apocryphal passion narrative the episode interesting for us may be summarized thus:

On Holy Wednesday, Jesus and his disciples go out to the Mount of Olives, where a rock miraculously announces the imminent betrayal of Jesus by Judas (1:3-20). The following morning, Judas goes to Jerusalem to meet the Jewish religious leaders for the first time, and he returns to 
the Mount of Olives with a servant of the high priest (1:21-31). Jesus then decides to travel to Bethany and celebrate the Passover in the house of Simon the Pharisee and his wife Akrosennā. Jesus sends Peter, James, and John to inform the couple of his arrival (2:1-9). [Jesus and his disciples arrive and have the Passover meal in Simon's house.] When Jesus expresses his wish to return to the Mount of Olives, Judas hurriedly leaves the assembly and runs to betray his master to the religious leader of Jerusalem. Jesus resurrects a rooster that Akrosenna had cooked and orders it to follow Judas (4:1-8). Concealing itself, the rooster spies on Judas in Jerusalem. First, the betrayer sleeps with his wife, who perfidiously advises him on the best way to deliver Jesus to his enemies. Next, Judas receives the reward for his betrayal, and he confirms with Saul of Tarsus the signal that will enable Saul to recognize and seize Jesus (4:916). At this point, the rooster swiftly flies back to Bethany and reports these events to Jesus and the disciples. In return for its services, Jesus sends the rooster to heaven for a period of one thousand years. [---] (4:1732). (Piovanelli 2003a: 429) ${ }^{12}$

According to Piovanelli, the rooster episode was mentioned already in 1859 by a French explorer Antoine Thompson d'Abbadie, who published it from a manuscript of his own Ethiopic collection, and Roger W. Cowley identified it as a part of the Book of the Cock in 1985. "This apocryphon enjoys a relatively large circulation within Ethiopian Christendom, where it has attained quasi-canonical status." (Piovanelli 2003a: 432-433; 433). Altogether 30 manuscripts preserved the text of it, either as an independent work, or as part of the Ethiopian Holy Week lectionary, the Acts of the Passion. The oldest ones were copied during the end of the 17 th and the beginning of the 18 th century, but it was the 14th century, when the translation was made from Arabic ${ }^{13}$ into Ethiopian. This was just the story that was mentioned by Thévenot (1665) and later by Father Michel-Ange de Vestigné (1734) as a well-known narrative among the Copts in Egypt (Piovanelli 2003a: 435-437).

As apocryphal parallels to the Ethiopic apocryphon Piovanelli mentions a Coptic fragment ascribed to the Book of the Resurrection of Jesus Christ by Bartholomew the Apostle ${ }^{14}$ and the $\mathrm{B}^{2}$ and $\mathrm{B}^{3}$ version of the so-called Greek "B" recension of the Gospel of Nicodemus that was discussed in this article above. The first one "narrates the resurrection of a cooked rooster during a meal shared by Jesus and his disciples - presumably by the Last Supper. In this account Apostle Matthias puts a platter bearing a rooster on the table, and he reports what the Jews said as he was killing it: 'The blood of your master will be shed like that of this rooster.' Jesus laughs and explains to Matthias that a crowing rooster who announces the light of dawn is a figure of John the Bap- 
tist, while a dead one is a figure of Jesus himself. For that reason, he will resurrect the rooster, in order that it may announce the day of his betrayal." (Piovanelli (2003a: 435-437). Piovanelli puts the story written in the Book of the Cock in some Jewish legendary context and explains the meaning of the motive of the cock coming back to earth one thousand years later as a messianic message (Piovanelli 2003a: 443-444). The anti-Paulinian tendency of the work, the placement of the Last Supper in Bethany et cetera inspires the author to date the first redaction after the Council of Chalcedon in 451. Otherwise, he thinks that the book "presents a truly topographic itinerary of the passion drama, with its characters - the good and the evil ones - its scen- ery, its miracles, and its relics" (Piovanelli 2003b: 124-125) and this topography was valid just in the fifth century.

The original text was written in Greek. [---] This Greek Book of the Cock, presently lost, could later have been translated into Coptic, [---] following the usual sequence of translation, the Coptic Book of the Cock was rendered into Arabic, and from Arabic into Ethiopian. (Piovanelli (2003b: 445-451)

R. Gounelle analyses the content of the texts of the Ethiopian homily and the Coptic fragment with numerous parallels from the Western legendary folk tradition. In comparison with the Coptic fragment, the symbolic references are not so visible in the Ethiopic narrative. The resurrection of the cock is described there as a magic act, otherwise there are many of this kind in the text. The Coptic fragment is rich of symbols, but the Ethiopic portrays the figure of Judas and especially his wife in a very detailed way (Gounelle 2003: 32). This fact gives an opportunity for an exhaustive feministic analysis: Judas is the only disciple who lives in a marriage, his wife initiates the betrayal, etc. The variation from the $E N$ stands closer to the Coptic one: the cock is not cut into pieces, Judas' wife does not play any role in the sin, nobody touches the cock, it stands up by itself in a supernatural way, etc. Gounelle ranks this "rope-variation" among the Western line of the dissemination of the plot, where Judas' wife and mother mutually take the same place (Gounelle (2003: 32-37).

\section{3. The cock miracle in the apocryphal Acta Petri and in the sacred legends}

The episode that we call cock miracle because of the emphasis on the story of Judas is understood in a broader sense in folkloristic literature, and in the encyclopedia of folk tales it was given the name "Roasted meat miracle", "Braten- 
wunder" (Wimmer 1978: 684-688). Reviving roast or boiled animals (fish, cow, calf, etc.), especially many kinds of bird (cock, hen, pigeon, peacock, partridge), appear frequently in legends in order to testify to the truth of a certain statement, or to its falsity. This narrative unit, in which the miracle is usually performed follows a provocative statement (Just as this roasted cock - hen, pigeon - will not revive, this or that thing will not happen), was called "the testimony of the dumb creature" by L. Kretzenbacher (1972). ${ }^{15}$ It is also a common characteristic of the versions that in each case the animal is killed and prepared for eating by humans. The folkloristic catalogues registered and numbered the motif of "The roasted cock crows" (Mot. E524.2.1., Cooked cock crows (Thompson 1966: 474); Tubach 1130, Cock rises at dinner, and Uther registered the Mot. E 524.2.1. as type ATU 630C, but did not include into the catalogue). Stith Thompson knows only one Danish record (Feilberg 18861914; Iv 272b); and Tubach cites the story (which was capable of actualization even in the time of the Reformation) from the 15th-century English and Spanish translation of the Alphabetum narrationum by Etienne Besançon:

Two companions are sitting at dinner with even a cut-up fowl before them. They say that the cock can never rise again even at St Peter's or Christ himself's command. The cock immediately comes alive, claps its wings, and crows. [Var. The scoffers are spattered by the cock and become leprous.] (Tubach 1969: 91).

Leander Petzoldt cites the story, reinterpreted in the time of Reformation, from a collection from the second half of the 19th century:

354. The Partridges of Mühlhausen. There are three partridges carved into stone on the church of Mary in Mühlhausen, and they commemorate the following miraculous event: Shortly after the beginning of the Reformation, which, as it is well known, soon had many followers in Thuringia, two Catholic prelates were sitting with some delicious food in front of them, and talking about the spread of heresy. However, one of them remarked that it is hard to imagine that the new teaching can be suppressed again. Then the other debater became so furious that he pointed to the three partridges that had just been served up, and exclaimed: 'Just as these three partridges, just brought out of the kitchen and pulled off the spit, will not rise again and fly away, the heretic teaching of that Augustinian friar will not prevail here, in this town! But miraculously, as soon as these prophetic words left the priest's lips, the roast moved before his eyes, the partridges rose, feathers grew on their bodies and wings again, then they clapped their wings, and flew out of the door before the 
eyes of the astonished drinking company. They ran after them, and saw them resting on a buttresses of the church of Mary; they petrified immediately, and they have been sitting there up to this day, as a miracle to be seen. (Petzoldt 1977: 52)

The two above narratives (there are two fellow diners having a conversation, one of them makes a certain provocative statement, which has some religious content in both cases - and this is of great importance -, then the miracle happens) are among the most "profane" versions of the type. The paradoxical testimony can be found most frequently in legends about the lives of saints, miracle narratives and exempla, and less frequently in New Testament stories of the Salvation. The scholarly literature (Köhler, Lehmann, Kretzenbacher, Wimmer) considers this whole bulk of medieval legend tradition to be of apocryphal origin, and is content with the reference to Tischendorf's publication. No one, however, has ever mentioned the fact that Tischendorf came up with only two manuscripts, and consequently it has never urged anyone to speculate about it. Nor about the fact that the Greek "B" version has never been translated into any other languages, therefore it is hardly possible that the narrative with the cock miracle, which became connected to Judas, got folklorized from the Greek manuscripts, kept in Paris and Venice.

Its essence is a real miracle, triggered by a provocative statement, which is due to divine intervention and neglects the basic laws of nature. In the European legend tradition this seems to be related primarily to the cult of saints: it serves to confirm the saints' proper and exemplary life strategy: the "ascesis narratives" belong here. The next group includes the miracle narratives, which reinforce the cult of saints, the belief that even after their death they intercede efficiently with God on behalf of those who appeal to them. The narratives related to the Salvation concern the most miraculous moments of Jesus' life: his birth and resurrection. In these stories the provocative statement comes from a person who doubts the miracle and the second miracle, visible and perceptible, ensues as a divine intervention, and verifies the first one. The stories about Herod, Mary and Judas belong here. The religious nature of the "two fellow diners" text type is crucial because it confirms our supposition that the narrative type itself spread, became popular, and abounded with variations as the cult of saints got established. It must have got into the Greek manuscripts of the Evangelium Nicodemi, which is cited as its source in scholarly literature, when it had already become well-known from hagiographies as well as from other genres of medieval religious literature. Its precedents can be found among the ancient sources of miraculous literature, namely in apocryphal acts of apostles, which "became influential from the 3rd century, and gradually transformed into the genre of hagiographic legends." (Adamik quotes 
Schneemelcher's opinion 1996b: 209). Erich Wimmer in his entry (Wimmer 1978: 686) refers to the story from the Petrusacten (Acta Petri, Acts of Peter). This brilliant idea was helped by the fact that when he was writing his work, the first volume of the Encyclopädie des Märchens had already been published, in which the entry "apocrypha" was written by the excellent theologian, Hans Conzelmann. He supposes the above apocryphal act to originate from the end of the 2nd century, and in the listing of its episodes, he mentions the following: "A smoked tuna comes alive" (Conzelmann 1976: 656). The earliest manuscript of the Acta Petri is the Actus Vercellensis 158, written in Latin at the turn of the 6th and 7th century; only a fragment survived from its Greek original; and it has a Coptic translation as well (CANT 190, Geerard 1992: 101).

Gounelle mentions more places from the Acta Petri (which is named here of Syriac origin), where dried animals are resuscitated and establishes that such adynata (impossible things) were spread not only in Egypt but everywhere in the Orient from the antiquity on (Gounelle 2003: 60). We quote here only one episode.

Apostle Peter "fights" with Simon Magus in Rome, converts many by way of his miracles, but some expect him to work further miracles in order to prove that he really is God's servant:

"13. Peter turned round and caught sight of a dried fish hung on the window. He grabbed the fish and told the people:

'If you saw this fish splashing alive in water, would you be willing to believe in Him whom I am advocating?'

Then they rumbled with one voice:

'Yes, we would believe you then!'

A pool full of water happened to be there. Peter started to pray: 'In your name, Jesus Christ, even if they do no not believe in You yet...! You, fish, come alive and swim, so that everyone here can see.'

Then he threw the dried fish into the water, and it came to life and started to swim. Many people saw the fish swimming, since Peter let it swim not only for a short time, but he made it swim longer so that others would not say it was only an illusion. [---] In the end some folks kept throwing bread into the water, and the fish ate all. [---] This sight made everybody believe in God [---]" (Dörömbözi (1996: 54-55). ${ }^{16}$

So the basic idea behind the cock miracle, "the testimony of the dumb creature" motif, emerged perhaps first in a biographical genre of the late Antiquity, the apocryphal acts of apostles, and it got inseparably attached to the holy narratives. A paradoxical statement of a skeptical person (that thing will not happen, just as this one), which is the fundamental element of the later legends and folklore narratives, is not present here yet; however, the miraculous 
revival of an animal prepared for eating similarly functions as a confirmation of belief.

We do not aim to describe the spread of the motif and its popularity in medieval European hagiographic literature in detail, just to present a few examples in some typological arrangement. We start their short and sketchy survey with the narratives of the ascetic saints. When analyzing the 15thcentury woodcut depicting the legend of Nikolaus von Tolentino, L. Kretzenbacher compiled a grandiose repertory of how this apocryphal motif emerged in the 11th-century Europe, became popular in the late Middle Ages, and, having revived in Baroque legendry, how it has been flourishing in the cults of local saints up to now.

The Bollandists of the Acta Sanctorum (ASS, Sept. III: 662) cite the Augustinian Nicholas of Tolentino's ( $† 1305)$ life from Jordanus v. Quedlinburg's (13001370?) work, the most significant 14th-century document of asceticism. The saint who vowed to fast became so weak that his prior ordered him to eat from the roasted partridge placed in front of him. He was supposed to obey, but did not want to break his vow of asceticism, so

"ingemuit, et elevatis oculis ad caelum, facto Crucis signo, manum ad perdicem posuit; et ecce perdix reviviscens, protinus avolavit..."

[he] sighed, and lifting up his eyes to the heavens, he crossed himself, and put his hands on the partridge, whereupon the partridge revived and flew away immediately...] (Kretzenbacher 1972: 438). ${ }^{17}$ The Bollandists deserve to be admired for becoming aware that this episode in the saints' life narratives is a topos whose truthfulness is open to doubt. Even the different biographies of Nicholas of Tolentino abound in rich, folkloristic variations of the motif: according to one, the partridge was not only roasted but also cut into small pieces, and when the saint crossed himself, it flew away with new feathers; according to another, there were two roast partridges; a third one accounts for the saint's main attribute, the star, too. When he sees the birds flying away, the saint lifts up his eyes to the heavens:

"Do volucres caelo, caelum mihi sidera reddit"

[I am giving birds to the sky, so the sky is giving me stars in return] (Kretzenbacher 1972: 438). They cite parallels from other hagiographies, such as that of the 6th-century British Benedictine hermit Gunther (BHL 3720), and that of his namesake, whose legend is worth quoting here from the original because of its Hungarian relevance. The Czech hermit Günther ( $† 1045$ ), being the Hungarian Saint Stephen's relative/subject ("cognatus sancti Stephani"), is listed among the Hungarian saints (Gombos 1938: 2437-2438). Just as the prior put 
Nicholas in a seemingly insoluble position, here the king does the same with the ascetic hermit.

Factum est autem, dum hora prandii Sanctus Guntherus mensae Regis pariter consedisset, Rex sibi pavonem assatum apposuit et ut carnibus vesceretur, intime flagitare coepit. Sancto autem viro sub regulari conversatione degente et huiusmodi cibis abstinente penitus contradicebat et illicitis cibis se contaminari nolle asserebat. Cuius voluntati Rex non minus resistebat, ut apposita manducaret, non solum rogando, verum etiam praecipiendo laborabat. Quidnam facere poterat? Praecepto regis se obtemperare promittebat, sed in divino adjutorio fiduciam retinebat. Quapropter factum est, ut inter prandentes hic solito more orationi insisteret, caput manibus inclinaret, profusis lacrymis, ne illicitis cibariis polluetur, divinam clementiam implorabat. Mira res atque stupenda! Completa Dei famulus oratione, caput de manibus elevabat, avis assata, mensaeque superposita, reddita vitae pristinae devolabat et ab eius usu gratia divina virum liberabat. Quo visu cuncti miraculo inaudito Deo gratias referebant, nec amplius sancti viri voluntati resistebant.

[When it was time to eat, Saint Günther sat down at the table with the king, and the king helped himself with the roasted peacock and urged him kindly to have some of the meat. But the holy man, who lived according to monastic regulations, was supposed to strictly abstain from this kind of food, so he did not want to consume any forbidden food. The king disapproved of his decision so much that he put it [the roasted peacock] in front of him, and not only asked but ordered him to eat. What was he supposed to do? He decided to obey the king's command, but he put his faith in God's assistance. So what he did was to bury his face in his hands while the others were feasting, and started to pray persistently in tears, and begged the divine clemency for not having to pollute himself with forbidden food. What a miraculous and amazing event! The wish of God's servant was fulfilled: as soon as he elevated his head from his hands, the roasted cock placed on the table returned to its former life, and flew away, and out of divine mercy freed him from having to eat it. Those present, upon seeing this, thanked God for the unheard-of miracle, and never again resisted the holy man's will.] (Acta Sanctorum (ASS) Sept. I. (1746), Num. 289, p. 529, A and B paragraphs, BHL 3713-3719.)

This legend of Saint Stephen is the only story with the "cock miracle" whose traces could be found in popular literature, in the media which directed the European legend tradition of apocryphal origin towards oral spreading, towards folklorization. There is one snag only: not even a single folklore parallel has been known up to the present day. In the Trattner-calendar for 1826, under the title "historical notes", the 2nd verse of chapter VII reads as follows: 
In King Saint Stephen's time there were many devout men in Hungary, and among these devout men hermit Gunter who worked the miracle at Saint Stephen's table that the roast peacock came alive and flew away. ${ }^{18}$

After the ascetic saints, let us mention the best known one of the miracle narratives of the sanctuaries: the legend of Saint James. On their way to Santiago de Compostela in Spain, two unfortunate pilgrims are suspected of stealing. One of them is sentenced to death and is hanged, but Saint James keeps the pilgrim who respects him and prays to him alive until the judge makes sure of his innocence. The convict's father begs the judge for his son, then still alive, when the judge is just having his lunch. 'Just as this roasted cock on my plate will not come alive, your son cannot be alive on the gallows!' says the judge, when the cock flies up, and calls all the people to the gallows. They find the pilgrims' patron, Saint James, there, who has been holding up the unjustly hanged man in his protective hands until they saved him (Kretzenbacher 1972: 445).

This cock miracle is not yet included in the 12th-century so-called pseudoCalixtine James legend, and it cannot be found in the Legenda Aurea (see above) either. It is included, however in the Passionale (ca. 1280-1300) and in Hermann von Fitzlar's Heiligenleben (1349). Since the 15th century it has almost never been absent from either the textual or the pictorial representations of the James legend (Wimmer 1978: 685). L. Kretzenbacher demonstrates the popularity of the legend by presenting the baroque James devotions of the churches in the Bavarian, Austrian, Italian, Slovenian Alps and the artistic representations of the miracle in the churches. Let us now mention a legend recorded at the beginning of the 20th century, a piece from Anton de Mailly's compilation published in 1922 , as one of the rare folklore data. ${ }^{19} \mathrm{~L}$. Kretzenbacher even cites examples of the legend with Saint Leonard in James' role, where he is depicted as the performer of the cock miracle, with birds flying up from the plate.

Köhler recalls a similar legend narrated by Ludovicus de la Vega:

The Moors captured a Spaniard who unceasingly prayed to Saint Domicius, the patron saint of his home town, Rigoria. One day, when the commander of the prison was sitting at the table, one of the prison guards remarked that this Christian might even be rescued by that saint due to his persistent praying. This cannot happen, interjected the master, just as the roast cock lying in front of me will not fly away and crow. As soon as the Moor uttered these words, the cock flew up and started to crow. They rushed to the cell immediately, where they saw great brightness, and the prisoner had disappeared. Saint Domicius set him free. (Köhler 1900: $227-228)^{20}$ 
The "testimony of the dumb creature" motif, in accordance with the mentality expressed in the apocryphal acts of apostles, was used in medieval hagiographies to confirm the belief in miracles. Baroque devoutness revived and reinforced this tradition. It was included in the medieval salvation narratives of apocryphal origin and in the poetic works on biblical themes for the same purpose, accompanying outstandingly miraculous events.

\section{4. The cock miracle in the narratives of the New Testament}

The miracle linked with the paradoxical statement, which could be used perfectly in stories about the apostles' missionary work and the saints' lives, proved to be suitable in popular piety as well for the stories of the gospels, especially those about Jesus' birth and resurrection, the greatest miracles of the greatest Christian holidays. In the oriental apocryphal works, in the Ethiopian homily (edited at the turn of the fifth and the sixth century, if Piovanelli's dating will be proved correct) and in the Coptic fragment (the author of it had to know the text of the Evangelium Nicodemi, so this work is probably later (Gounelle 2003: 62) as well as in the Evangelium Nicodemi's Byzantine forms $\left(\mathrm{B}^{2}, \mathrm{~B}^{3}\right.$, edited between the nineth and the twelfth century) the cock miracle have already taken its place in the Story of Salvation. Starting from the 11th century, a narration is known in the West which tells that Herod did not want to believe the Magi's report on the birth of Jesus just as "he did not believe that the cock in the plate in front of him would grow feathers and fly away." But the cock did so. The legend of Jesus's birth got from the "Orier le Danois", a chanson de geste attributed to Raimbert von Paris into English" ${ }^{21}$, Scandinavian, and Slovenian (Grafenauer 1958: 65ff.) balladry, and into the legend of the protomartyr Saint Stephen. In the popular versions it is him, not Magi, who informs Herod (Kretzenbacher (1972: 444-445). Köhler mentions a song from Bretagne and another chanson de geste in connection with the Herod story (Köhler 1900: 227).

He lists some additional data in a supplement, and makes a reference to a late medieval religious poem of instruction entitled Cursor Mundi, written in Northern English dialect in the first quarter of the 14th century. The book consists of 30,000 eight-syllable lines in rhyming couplets, including prologue and appendices. It tells the history of mankind based on the Old and New Testaments, hagiographic works and other sources, from the Creation to the Last Judgement. It was founded on a 12th-century Latin work (Leach 1949: 249; editions of the work: Morris 1874-93; Drabble 1995). The Judas story already appears here as follows: Judas, in contrast to his mother, states the 
impossibility of Jesus' resurrection, whereupon the miracle ensues (Köhler 1900: 640). ${ }^{22}$ According to the Standard Dictionary of Folklore, this is the same as what happened to Judas' wife in the manuscripts of The Gospel of Nicodemus as we could see; and this motif frequently occurs in European, English and Scottish balladry and among Christmas carols (Leach 1949: 250). The latter ones probably contain the Herod version (see above). It is also pointed out here that in Western Ireland the legend circulated in a version not mentioning the figure of Judas.

A group of soldiers, set to guard the tomb of Christ, were sitting on the ground around the fire. They were boiling a cock in the pot for their morning meal. And they were troubled in their minds, for it was said that Christ would rise from the dead and walk out of the tomb. One of them, however, believed no foolish tales; he declared Christ would not rise, 'no more than the cock in the pot'. Whereupon the cock jumped out of the pot and crowed, and at daybreak Christ rose and came out to them.

It can be declared of the Judas tradition that among the relevant texts there are only quite a small number of those including the cock miracle. ${ }^{23}$ One of these, quite similar in content to the version in the Evangelium Nicodemi, is quoted from Edelestand du Méril's 1847 compilation by Kretzenbacher: a medieval French poem, allegedly popular despite being written in Latin (du Meril 1847, cf. Kretzenbacher 1972: 444). This is the story of the "deplumed, partly cooked" cock ("gallus deplumatus, semicoctus") in the pot of the unfortunate mother of the Judas Iscariot, who, having betrayed the Redeemer, returned home.

Out of the balladry not discussed here in detail, let us mention the 19thcentury Estonian song by Jakob Hurt, and one from Ingermanland, published by Julius Krohn, as examples of the folklore occurrences of the motif. ${ }^{24}$ In both of these, the skeptical person is Mary, who does not believe his son's martyrdom until the cock miracle compels her to do so. Interestingly enough, R. Gounelle and not a folklorist cites the greatest store of folk poetry, namely from the Romanian one, published by Simeon Florea Marian in the early 1900s. The several texts are partly in prose, partly in a verse form (carols), and were collected by S. Fl. Marian from oral performance of gymnasium students and peasants, or republished from local journals and newspapers at the end of the 19th century. The variants represent the territories of Transylvania, Moldavia and Bucovina (Gounelle 2003: 39-42; Marian 1904: 112, 178, 220-221, 224, 248, $300-301) .{ }^{25}$ 
In Romanian folklore it seems, at least on the basis of texts published by Marian (the work of his cited here contains mostly legends concerning the Virgin Mary), that the miracle of the cock is either proof that Mary is the mother of God or, and this is more common, is built in the colindas' narrative of the life of Jesus into the cycle of "Mary seeking her son", although Mary does not always partake in this scene. The event takes place either at the beginning of the Passion, in the episode that unravels in front of Pilate, or in the end, after the Crucifixion.

Gounelle designates the subject as the motif of the "singing roasted cock" (le coq cuit qui chant) and considers its inclusion in the cycle of Mary seeking her son (À la recherche de Notre Seigneur Jésus le Christ par se Mère) in Romanian colindas as a secondary development that hypothetically came about as a result of the micro-environment. This is further confirmed by Polish data, Gounelle asserts, incorrectly. ${ }^{26}$

Finally, he states that the relationship of these texts to the Gospel of Nicodemus and the above mentioned Latin legends must be treated with some reservation. It is noteworthy that these events always take place after the capture of Christ, and Judas and other female figures do not appear in them (who before the inclusion into the cycle of Mary seeking her son were present, Gounelle 2003: 4344).

The Polish data (Zowczak 2000: 348-349) are the result of fairly recent collections. A text written down in 1991 in the region of Soleczniki is very close to the $E N$. It is distinctive in that in this version Judas' wife takes the side of Jesus and scolds her husband upon his return home:

- You, this was a man who brought the dead back from their graves, why did you betray him?

In this instance the formula of impossibility is heard from the mouth of Judas:

- He too said that, that in three days he will rise again: he will rise as surely as this cock will rise and begin to crow!

The narrator of the text that originates from the area around Vilnius confuses the wife of Judas with the wife of Pilate (Claudia Procula, Prokla), who according to apocryphal texts was herself Christian or someone who sympathized with Christians, as did Pilate himself (see above on the Greek version of $E N$ ). With regards to the cock referred to by Judas, its coming back to life is usually linked to the "doubting" Jews, since they are "collective Judases" and are frequently referred to by this name: 
...when these Judases tortured the Lord Jesus, they slaughtered a cock and threw it onto a plate and cooked it and said: "Let him come back to life as this cock would come back to life". At this moment the plate overturned and the cock came back to life and began to crow. (District around Vilnius, 1990.)

The eastern Slavic texts that were uncovered during the expeditions researching a Biblical text, which were undertaken in 1981 in various parts of the Soviet Union and led by members of the Institute of Slavonic Studies in Moscow, remain entirely unknown even in the secondary literature. In the 1990s a program under the names "Folk Pravoslavia" (the Slavic term for the Orthodox or rather the Greek Eastern faith, in effect it designates folk religiousness) and "Folk Bible" was also initiated. The questionnaire used in the course of the fieldwork was published in 2002 by O. V. Kaspina and A. B. Moroz. Under number 17 on the questionnaire, are included the questions that relate to Judas (who was Judas, what sorts of stories did the participants know suggesting that he was conceived on a day of fasting, for example on a Friday, that he killed his father, that he married his mother, etc., did they know any stories of a baked cock coming to life on his table? Kaspina \& Moroz 2002: 120). Kaspina also included a few model texts as part of the same publication (Kaspina 2002). The corpus of text of the earlier collecting initiative was published in 2004. In the commentaries of certain texts, the editor Olga Belova also alludes to the already published Eastern Slavic parallels. This collection contains thirteen texts that are of relevance here, but other publications also came out on the collecting done in recent years, thereby making the picture that had taken shape of folklore variants of the turn of the twenty-first century known up to now far more colorful.

The condition of animals prepared for consumption is deficient not only because the animals have been roasted or cooked (in one of the Romanian colindas the cock is boiled for three days and three nights in order to demonstrate that the animal was not undamaged, or in legend poetry the cock is described as already having been carved), but also because they have been stripped of half their bodies or their flesh. Christ puts together the bones of the cock that Judas has eaten and then revives it, or the fish that the Mother of God ate comes back to life, or a little chicken hatches from a cooked egg (Belova 2004: 341, 366). ${ }^{27}$

It is impossible not to notice the common feature of the above mentioned texts, the hostility towards Jews. The most frequent scene (as is the case in the Romanian colindas as well) is the miracle that takes place at the table of the Jews during a meal, regularly appended with an ending that explains the 
origins of freckled skin, regarded as a typical feature of Jews. Belova refers to Bulgarian legends in which tinea (scabies?) thus forms on Jews. In Hucul legends the Jews who did not believe in Jesus' resurrection were ruthlessly punished; they went blind, their eyes burnt when fiery drops fell in them (as in the above Romanian colindas), or they turned to stone (Belova 2004: 368). ${ }^{28}$ The latest research concerning the history of the Passion narrative examines this aspect as well. ${ }^{29}$ Hostility towards Jews became a strong component of Central-Eastern and Eastern European texts, just as hostility towards women became a prominent feature of Ethiopian texts. A Ukrainian text from Galicia is noteworthy in this respect. In it the protagonist happens to be a Jewish prophetess who became a Christian martyr and whose positive prophecy was affirmed by her "colleague," the old Jewish seer. Both of their roles are cast in an explicitly positive light.

In view of the rich early Transylvanian, Moldovan and Bucovinan collections (we do not know of any new ones), we can safely suppose that it is only due to the lack of interest on the part of fieldworkers that the Hungarian material remains so scanty. We know of merely two entries: the first one is from a collection conducted between 1971 and 1973 by Anikó Salamon in Lunca de Jos (Gyimesközéplok), Valea Rece (Hidegség pataka) (Harghita county, Romania).

Then they drove Jesus to Calvary Hill and crucified him. He hung there for three days and then died. Then they took him down and buried him and used buffalos to pull large stones onto his grave. Then three days later the holy angels went and pushed them aside and set Jesus free.

Then he arose from the grave and went up into heaven, leaving the earth behind.

But when Christ rose and emerged from the ground, they all were taken aback that even though they had buried him he emerged from the ground. Because when they buried him they had said that Jesus will emerge from the grave when roasted fish splashes water from the platter and the cooked cock flaps his wings on the table and crows. Then the fish splashed water from the platter and the cock crowed, do you understand?

Well, the Jews then grew frightened. "Well, the saint man has come out of the grave." They went, he was not in the grave, he was gone, he had risen and went up into heaven.

The Jews became freckled when the fish splashed water from the plate and the cock splashed fat from the plate and flapped his wings on the table and crowed.

And since then the Jews have been freckled. 
The second one was collected in Moldavia in 1991 from a young man, aged twenty:

Jesus was laid into the ground, then the Jews roasted a cock for Easter, and a Jew said: 'Jesus will rise only if this cock crows and claps its wings three times'. Then they placed a Jew there to guard Jesus so that he would not run away in case he revives. And the cock crowed, clapped its wings, whereupon Jesus came alive, rose, and went up to Heaven. Then they reached out to catch his legs, but they couldn't. See, that's why there are some people with yellow spots on their face; and it is said that the cock, when clapping its wings, spattered them with grease, and this is why those yellow spots are on their face. (Bosnyák 2001: 91) ${ }^{31}$

The Hungarian legends belong to the most frequent redaction of similar Romanian and Eastern Slavic narratives, but only to the extent that the miracle happens after the death of Christ as testimony to his resurrection to astound those in doubt. Otherwise they are for the most part comparable to the gravescene from Western Ireland cited above from M. Leach. It is noteworthy that although in the Moldovan text the Jews figure simultaneously as guards and disbelievers, the punishment, the appearance of freckles does not become their collective punishment. These texts follow the tendency of the folklore narratives in which, as long as a basic story is suitable for explaining the origin of a certain phenomenon in the world, an explanatory clause, which puts this very development into words, is added to the end of the story. The same etiological clause can be found in the Romanian texts as well, the difference is that these clause have some anti-Semitic color (the Jews have spots on their face, in one story even the paprika is mentioned because of its red color). The written sources never include anything like this, not even in the case of the cock miracle. Nevertheless they carry this potential. The medieval text by Etienne Besançon (see above) reported only that those who got spattered with the grease of the cock clapping its wings became leprous. While the same narrative motif is part of a single event, it becomes an "explanation of the world": "there are some people with yellow spots on their face," since they have not existed before. Here the topic of the resurrection story includes the origin, or rather the creation, of freckled people as well. In his legend, Nicholas of Tolentino makes the partridges fly towards the sky and gets stars in return, and they become his attributes. The Ethiopic Book of the Cock, the folkloristic Coptic data, tell about the cock ascending to the sky. In spite of the theological interpretation of this motive as a Christ symbol, it would not be surprising if other stories came to light, linking, for example, the formation of a constellation to the cock mira- 
cle, since it would be quite an obvious idea that these birds have been visible in the sky up to now in some form, just like the petrified ones on the church of Mühlhausen, still proclaiming the miracle. As we could see, the scholarly literature specifies certain pieces of the French chanson de geste as the intermediary source of the cock miracle motif in western and northern European balladry. In the case of the Hungarian variant, no mediatory source has been found so far. It seems to be borrowed from the Romanian neighborhood, where this traditional material might be the relic of medieval European culture, which has survived, varied and spread in orality. But, as in similar cases, thorough review of the Slavonic apocrypha will be necessary, especially that of the manuscripts copied in Romanian monasteries. Summing up what has been said:

1. We believe that the original source of the cock miracle is the orality of the late antiquity, from which it got into the apocryphal acts of apostles, hagiographies, miracle narratives and the apocryphal salvation story during the Middle Ages.

2. The late manuscripts of the Gospel of Nicodemus are not the sources but only the records of a tradition popular all over Europe, and the Christian Orient, which spread in writing and supposedly in orality as well. After all, at the time of their appearance it had already been known in Western legendry. According to the latest philological research, the Greek "B" version of the Gospel of Nicodemus, which the two manuscripts known so far belongs to, has never been translated. The Ethiopian and the later Coptic apocryphal books also belong to these late extended sources that can be considered a folklore compilation.

3. In order to interpret the Hungarian folklore data, in particular those presented here, it would be necessary to explore the Hungarian reception of the apocryphon known as Gospel of Nicodemus thoroughly, and the historical elaboration of Slavic (and even more so the Romanian) apocryphal tradition, folk liturgy (Passion), and last but not least consideration of the products of intermediary, popular literature. The folklore tradition, rich in variations, nevertheless still appears homogenous enough for us to presume a common source. In conclusion, it seems important to note that with respect to the origins of the motif - precisely because of the novelty of the proposition - a verified, permanent answer cannot be provided; beyond our knowledge of the facts we can only speak of hypotheses. Gounelle's view, formulated in 2003, is not in harmony with that worked out the same year, if perhaps a bit later, by Piovanelli. ${ }^{32}$ 


\section{ACKNOWLEDGEMENTS}

This paper was prepared with the support of OTKA fund No. T043071. This English version is a bit a reduced one: the full text was published in Hungarian: Nagy Ilona: A sült kakas kukorékol. Az apokrif irodalomtól a folklórig. Pócs Éva (ed.): Maszk, átváltozás, beavatás. Vallásetnológiai fogalmak tudományközi megközelítésben. (Tanulmányok a transzcendensről. V.) 2007, Budapest: Balassi Kiadó, 495-533, and will be published in German: Acta Ethnographica Hungarica, 2007, 52, 2. The translations of texts from German and Latin into Hungarian were made by the author, from Russian by the author and Ágnes Kriza, from Old Greek by Péter Tóth, from Polish by Piroska Szabó, and from Rumanian by students of Sapientia University, Csíkszereda/Miercurea Ciuc, Romania, Edit Mária Danél und Julia-Georgéta Stan.

\section{COMMENTS}

1 The Grail legend appeared together with the Gospel of Nicodemus in England: the story concerning Joseph of Arimathea, the founder of Christianity in Britain comes from the Acta Pilati. He was the guardian of the Holy Grail and became the apostle of Britain. The Middle English version of Gospel of Nicodemus (British Museum MS Harley 149), containing the whole text of it, was written between 1475 and 1500 (cf. Lindström 1974: 11).

2 The earlier, for example, mentions the English translation of the Irish $E N$ as McNamara 1975: 68-75, two years later the Clavis (CANT) already represents its new edition: Herbert \& McNamara 1989. But only Gounelle \& Izydorczyk (1997) gives an information about an edition in modern Irish language: Hughes 1991. This bibliography helps to complete some, from the earlier missing data, for example, the names of publishing houses. In Geerard's Clavis there were published such recent editions as Thomson 1985, with supplements and corrections to Santos Otero (1981), or the modern, Georgian edition of the $E N$, containing its all available manuscripts: K'urc'ikiże 1985.

3 "Secundo quaero circa illum textum: E $\mathrm{l}$ i a s e s $\mathrm{t}$ u? numquid ignorabant iudei, Johannem esse filium Zakariae? Respondeo quod ignorabant, quia ut habetur in ewangelio Nicodemi, ex quo Johannes a sua matre in infantia ductus fuit in desertum propter tyrannidem Herodis, qui in Betlehem et in omnibus finibus eius iusserat omnes puros occidi, et in illo deserto nutritus fuit, et sic venerat in oblivionem iudaeorum." (Szilády 1910: 111). This part of the text probably belongs to Descensus 18. 1. Here I would like to express my gratitude to Péter Tóth, research fellow at the University Library of Budapest, for his constant and valuable support in finding references and new scholarly literature to my article.

4 The work cited by Fabricius: Relation d'un voyage fait au Levant. Mémoire sur la collection des grandes et petit voyages et sur la collection des voyages de Melchisedech Thévenot ...Paris, Baudin. (1802: 501, the page number here accoding to Kretzenbacher 
(1972 : 444). First edition: I, Paris, 1665: 502, according to Gounelle 2003: 30. The page number is very different at the different authors.

5 "parte primo Itinerarii lib. 2. capite LXXV. ubi de Coptis, p. 361."; "Es gehen viel aus denen Apocryphischen Büchern derer sie sich noch bedienen bei ihnen im Schwange. Uns ist von dem Leben unsers Heilandes in seiner Kindheit nichts bewusst, allein sie haben viel p a r t i c u l a r i t a t e n davon.[---] und sagen es sei alle Tage ein Engel vom Himmel kommen und demselben zu essen gebracht/ingleichen/ dass er zu seiner Zeitvertreib kleine Voegel aus der Erden gemacht/nachmals darauf geblasen / in die Lufft geworffen und davon fliegen lassen." (Fabricius 1719: 156).

6 "Sie gehe vor man habe am Tage der Einsetzung des heiligen Abendmahls dem Herrn Christo einen gebratenen Hahn aufgetragen und als Judas weggegangen wäre den Herrn zu verkauffen hätte er ihm befohlen aufzustehen und dem Judas nachzufolgen, welches der Hahn gethan und nachmaln dem Herrn Christo verkündiget wie ihn Judas verkauffet und deshalben würde derselbe ins Paradies mit eingehen." Ibidem 157.

7 Gounelle (2003: 20 and passim) used only Kretzenbacher's two earlier and shorter articles: "Der Hahn auf dem Kirchturm. Sinnzeichen, Bibelexegese und Legende". Rheinisches Jahrbuch für Volkskunde 9 (1958: 194-206), und "Pilgerfahrt nach Maria Luschari”. Süddeutsches Archiv 3 (1960: 87-100).

8 Only the first volume was published.

9 "B i. e. Paris Reg. nunc Nat. [Bibliothèque Nationale, I. N.] 808, saeculi XV. (Thilonis B). Hunc textum ex Thilonis commentario sumsimus; diversas enim huius recensionis partes tantum non omnes ad marginem descripsit" (Tischendorf 1876: LXXIII).

10 "C i. e. Ven. Marc. [Venetus Marcianus, today Venice, Biblioteca Nazionale Marciana. I. N.] class. II. cod. LXXXVII. olim Nanianus CIX. saeculi XV. Plura inde studio Morellii hausta (vide ante) iam Thilo composuit cum textu codicis B. Nos etiam hunc textum ex codice totum transscripsimus" (ibidem).

11 Piovanelli (2003a: see the title).

12 Piovanelli's French translation will be the first rendering of the Book of the Cock in any contemporary language and will be published in Geoltrain and Kaestli, 2007.

13 "Until recently, no trace of any Arabic manuscripts of the Book of the Cock had been discovered." Piovanelli 2003a: 437, notice 25. Pionavelli has learned from personal communication about a manuscript identified as an Arabic version, its publication is underway.

${ }^{14}$ A fragment of it was published by P. Lacau in 1904, another one by É. Revillout in 1907, new editions and translations were published just in the last years (JeanDaniel Kaestli and Pierre Cherix 1993, Matthias Westerhoff 1999, and Enzo Lucchesi 1997). Piovanelli (2003a: 437), Gounelle (2003: 21-22).

15 "Zeugnis der stummen Kreatur."

${ }^{16}$ From the viewpoint of this article it was not so important to use an English translation from the original language. 
${ }^{17}$ Further data are used from the same page.

18 Trattner Mátyás Magyar Nemzeti Kalendárioma 1826. Esztendöre. Nyomatott A' Kiadó Könyvnyomtató Intézetében, Pesten, 1825. [Mátyás Trattner's National Calendar for the year 1826. Printed in the Press of the Publishing House] OSzK [Hungarian National Library] 855/1826. See Mikos (2005: 174). A special thanks to the author for her helpful information.

19 114. Il miracolo di San Giacomo. The sentence of crucial importance: "E possano volare, questi due polli arrosti se ancora dubitate!” Mailly (1993: 149-150).

20 The saint's name is correctly: Dominicius Calceatensis, "who was known as a person, who is the strongest in liberation of captives" (Acta Sanctorum, ASS, Majus, tom. III. 1680. Antverpiae: apud Michaelem. p. 171. punctum 6. BHL 2237). Otherwise the source for ASS was the work of fray Luis de la Vega: Historia de Santo Domingo de la Calzada, Búrgos, 1606. This data from the website.

${ }^{21}$ For example, “The Carnal and the Crane” (Child Nr. 55) (Moser 1974: 139).

${ }^{22}$ Köhler points out Cursor Mundi p. $913 \mathrm{f}$. as his source, but it is quoted from the work of Mussafia 1869: 63, p. 206 (Köhler 1900: 227).

${ }^{23}$ The apocryphal Judas' biography does not contain this episode. See more Worstbrock (1983: 882-887), Brednich (1993: 672-676). The scholarly literature on Judas (not mentioning Lehman's work) does not deal with the cock wonder, better with the Judas legend, as a christianized variant to the Oedipus legend (Puchner 1994: 305309 ), or with the legend about the silver coins of Judas (Kretzenbacher 1961: 1-17). Kretzenbacher's work (1972) cited many times in our study, deals with the Judas story only per tangentem, nevertheless it counts as the most competent in this theme.

${ }^{24}$ Krohn, Julius sine anno: Kantelettaren tutkimuksia. II. 174 ff.; Eisen, M. J. \& Kallas, O. 1932: Eesti rahvalaulud (Estonum carmina popularia) aus der Sammlung J. Hurt. II. Dorpat. S. XIII. Cf. Kretzenbacher 1972: 445.

${ }^{25}$ Gounelle cites the relatively new work of Zowczak (2000) with Polish variants as well.

${ }^{26}$ Gounelle (2003: 42) refers to Zowczak (2000: 349). He misunderstood the Polish text, in which there is reference to a Romanian colinda: "The Romanian legend joins the two stories [meaning the one occurring during the Last Supper and the one narrating the miracle of the resurrection of Jesus - I. N.]: Mary seeks Jesus. According to Frederic Tailliez this episode is the explanation of the section of the Psalmus in which the enemies of Jesus hold a feast after their heinous deed. The Holy Virgin meets with the Jews, who feast beside the table/cross near the grave. "Your son will resurrect when this cock begins to crow, when this fish in the sauce begins to swim." Work cited: Talliez, F. (S. J.) 1952: La Vierge dans la littérature populaire roumaine. In Maria. Études sur la Sainte Vierge 2. Sur la direction d'Hubert du Manoir, S. J., Paris, 293.

${ }^{27}$ Belova's notes refer to early $(1895,1902)$ Russian and Ukrainian publications of texts. 
28 The Bulgarian data are from the Archive of the Folklore Institute of the Bulgarian Academy of Sciences; in the case of the Hucul legends Belova refers to the 1912 publication of Onishtshuk.

${ }^{29}$ With regards to this, in footnote 11 Piovanelli (2003b: 103) lists, for example, the works of John Dominic Crossan, among them 1995.

${ }^{30}$ Salamon (1987: 172, no. 156). Narrated by Ilona Daradics, 69 years old.

${ }^{31}$ Retold by Péter Legedi, Hungarian, born in 1971, Klézse, (Cleja), Romania.

32 "Accordingly, in the essay the story of the roasted cock crowing appears as follows: The saying of Ambrose of Milan (who speaks of the cock exposing the behavior of those who are talking) can presumably be derived from a parable that spread in the West during the eleventh century in various contexts, extending into the twelfth and first half of the thirteenth centuries, and which was used to create the image of the incestuous parent-murderer Judas. This also included a short narrative of how he betrayed Jesus. This story, which spread in the narratives of the cross, was transferred into the Greek world and was utilized in the Byzantine Greek version of the Gospel of Nicodemus. From the beginning of the thirteenth century the tale of the resurrected roasted cock intertwines with the stories of the massacre of the innocents. Beginning with the fourteenth century it appears in the legend of Saint James of Compostela. It migrated from here into the cycles of the legendaries of Saint Dominic and Mary. Other traditions which might be difficult to date should be mentioned: In Poland there are entries from no later than the seventeenth century, in Congo from before 1682, in Hungary the story is known from before 1745, and there are data from Romania and Ireland as well. It is difficult to pinpoint in Eastern literature. Two Coptic fragments attest to its existence: 1 . the story of Matthias, 2. the homily that tells of the betrayal of Judas. It is evident that concerning Judas there were correspondences with western traditions. The author of this apocryphal text must have been familiar with the Gospel of Nicodemus. The various features do not make it possible for us to talk of simple adoption of western motives. It has motives that are connected to Coptic Christianity. The hypothesis according to which this milieu utilized the motif of resurrection of the cock in a distinctive way cannot be dismissed, even if the elements suggesting this are not overwhelmingly supported. Our hypothesis remains just that, a hypothesis. If we say that our analysis is not sufficiently well-grounded, we insist that the link between this legend and the text of the Bible is more tenuous and complex than we might think. [---]" Gounelle (2003: 62 ). It is only in this text that Gounelle refers to the Hungarian data, without notes. Unfortunately we do not know what he has in mind. The data from Congo is also inexplicable." 


\section{REFERENCES}

Acta Sanctorum (ASS) 1643-1940. Published by Bollandistes, Antwerpen and Bruxelles. Vols. 68

Adamik Tamás 1996a. Utószó [Epilogue]. Dörömbözi (szerk.) [ed.] 1996, pp. 199_ 210.

Adamik Tamás (transl.) 1996b. Feljegyzés a mi urunkról, Jézus Krisztusról, amely Pontius Pilátus idejében készült. [Recording about our Lord, Jesus Christ, made in the time of Pontius Pilat]. Csodás evangéliumok. [Wonderful Gospels] Válogatta és az utószót írta Adamik Tamás. [Selected and wrote the epilogue Tamás Adamik]. [Apokrif iratok. [Apocryphal writings] Sorozatszerkesztő Adamik Tamás.] [Editor of the series Tamás Adamik]. Budapest: Telosz, pp. 117-140. Jegyzetek [Notices], pp. 175-180.

Adamik Tamás 1996c. Utószó [Epilogue]. Ibidem 181-191.

ATU $=$ Uther 2004.

Belova 2004 = Белова, О. В. (сост. и комм.) 2004. Народная Библия. Восточнославянские зтиологические легенды. [Folk Bible: Western Slavonic Ethnological Legends.] Отв. ред. В. Я. Петрухин. Москва: Индрик. (Традиционная духовная культура славян. Публикация текстов)

BHL = Bibliotheca Hagiographica Latina Antiquae et Mediae Aetatis 1898-1901. Ed. Socii Bollandiani. Bruxellis: Socii Bollandiani.

Bosnyák, Sándor 2001. Magyar Biblia. [Hungarian Bible]. Budapest: L’Harmattan. Brednich, Rolf Wilhelm 1993. Judas Ischarioth. Brednich, Rolf Wilhelm (ed.).

Enzyklopädie des Märchens. Handwörterbuch zur historischen und vergleichenden

Erzählforschung. Bd. 7. Berlin \& New York: Walter de Gruyter, pp. 672-676.

Conzelmann, Hans 1976. Apokryphen. Ranke, Kurt (Hrsg): Enzyklopädie des Märchens. Handwörterbuch zur historischen und vergleichenden Erzählforschung. Bd. 1, Lief. 3. Berlin \& New York: Walter de Gruyter, pp. 628-662.

$C A N T=$ Geerard 1992.

Crossan, John Dominic: Who killed Jesus? Exposing the Roots of Anti-Semitism in the Gospel Story of the Death of Jesus. San Francisco: Harper, 1995.

Cullmann, Oskar 1959. Kindheitsevangelien. Hennecke, Edgar \& Schneemelcher, Wilhelm (eds.) 1959. Neutestamentliche Apokryphen in deutscher Übersetzung. I. Band.

Evangelien. 3, völlig neubearb.Aufl., hrsg. von W. Schneemelcher.Tübingen:Verlag v. J. C. Mohr, pp. 272-305.

Drabble, Margaret 1995. The Oxford Companion to English Literature. Revised edition, Oxford: Oxford University Press.

Dörömbözi, János 1996. Az apostolok csodálatos cselekedetei. [Wonderful acts of the apostles] [Apokrif iratok. Sorozatszerkesztő Adamik Tamás.] [Apocryphal writings. Editor of the series Tamás Adamik] Budapest: Telosz.

Fabricius, Johannes Albertus 1719. Codex Apocryphus Novi Testamenti. Collectus, castigatus, Testimoniisque censuris et Animadversionibus illustratus a J. Fabricio S. S. Theol. D. Professore Publ. et h.t. Gymnasii Rectore. Hamburgi, Sumptib. Benjam. Schiller, Anno 1703. Editio secunda, Vol. I-II. emendatior et tertio tomo, separatim venali, aucta. Hamburgi, Sumptu Viduae Benjam. Schilleri et Joh. Kisneri. 1719, 156. 
Feilberg, H. F. 1886-1914. Bidrag til en ordbog over jyska almuesmål. 4 vols. København: H.H.. Thieles Bogtrykkeri.

Edelestand du Méril, M.1874. Poésies populaires du moyen age. Paris.

Geerard, Mavritii 1992. Clavis Apocryphorum Novi Testamenti (CANT). (Corpus Christianorum, Series Apocryphorum). Turnhout: Brepols, pp. 43-48.

Geoltrain, Pierre \& Kaestli, Jean-Daniel (eds.) 2007. Écrit apocryphes chrétiens, vol. 2. Bibliotheque de la Pléiade. Paris: Gallimard.

Gombos, Albin 1938. Catalogus fontium historiae hungaricae III. Budapest: Szent István Társulat, pp. 2437-2438.

Gounelle, Rémi 2003. T propos des volailles cuites qui ont chanté lors de la passion du Christ. Recherches Augustiennes 33, pp. 19-63.

Gounelle, Rémi \& Izydorczyk, Zbiniew 1997. Thematic Bibliography of the Acts of Pilate. Izydorczyk, Zbigniew 1997: 419-532.

Grafenauer, Ivan 1958. Bogastvo i unboštvo v slovenski pesmi i v irski legendi. Abhandlungen der Slowenischen Academie der Wissenschaften und Künste, Philologische und Literarische Abteilung, Bd. 4. Ljubljana.

Günter, Heinrich 1949. Psychologie der Legende. Studien zu einer wissenschaftlichen Heiligengeschichte. Freiburg im Br.:Verlag Herder.

Hartwagner, G. 1976. Nikolaus von Tolentino. Braunfels, Wolfgang (hrsg. von) Kirschbaum, Engelbert (begründet von). Lexikon der christlichen Ikonographie. Bd. VIII. Ikonoraphie der Heiligen. Meletius bis zweiundvierzig Martyrer. Register. Freiburg im Br.: Verlag Herder.

Hennecke, Edgar \& Schneemelcher, Wilhelm (Hrsg.s) 1959. Neutestamentliche Apokryphen in deutscher Übersetzung. I. Band. Evangelien. 3, völlig neubearb. Aufl., hrsg. von W. Schneemelcher. Tübingen: Verlag v. J. C. Mohr.

Hennecke, Edgar \& Schneemelcher, Wilhelm 1990. Neutestamentliche Apokryphen in deutscher Übersetzung. I. Band. Evangelien. Hrsg. v. Wilhelm Schneemelcher. 6. Auflage der von Edgar Hennecke begründete Sammlung. Tübingen: Verlag v. J. C. Mohr (Paul Siebeck).

Herbert, Maire T. \& McNamara, Martin 1989. Irish Biblical Apocrypha. Selected Texts in Translation. Edinburgh: T \& T Clark, pp. 60-88.

Hughes, I. (ed.) 1991. Stair Nicoméid: The Irish Gospel of Nicodemus. Irish Texts Society, vol. 55. London: Irish Text Society.

Ivanova 2002 = Иванова, А. А. (отв. ред.) и др. 2002. Актуальные проблемы полевой фольклористики. [Topical Issues in Folkloristic Fieldwork] Сборник МГУ им. М. В. Ломоносова. Фил. фак. Каф. рус. устного нар. творчества. Москва: Издво Моск. ун- та.

Izydorczyk, Zbigniew 1997. The Evangelium Nicodemi in the Latin Middle Ages. In: Izydorczyk, Zbigniew (ed.) 1997. The Medieval Gospel of Nicodemus. Texts, Intertexts, and Contents [Medieval \& Renaissance Texts and Studies, vol. 158]. Tempe, Arizona: Arizona Board of Regents for Arizona State University. pp. 43-101.

Izydorczyk, Zbigniew \& Dubois, Jean-Daniel 1997. Nicodemus's Gospel before and beyond the Medieval West. In: Izydorczyk, Zbigniew (ed.) 1997. The Medieval Gospel of Nicodemus. Texts, Intertexts, and Contents [Medieval \& Renaissance Texts and Studies, vol. 158]. Tempe, Arizona: Arizona Board of Regents for Arizona State University. pp. $20-41$. 
Kaspina 2002 = Каспина, М. М. 2002. Народная Библия. Иванова 2002: 117-120. Kaspina \& Moroz 2002 = Каспина, М. М. \& Мороз, А. Б. 2002. Народное православие. Иванова 2002: 111-117. Библия в устной традиции. ibidem 160-175.

Köhler, Reinhold 1900. Kleinere Schriften zur neueren Literaturgeschichte und Wortforschung. Hrsg. von Johannes Bolte. Berlin, Verlag von Emil Felber.

Kretzenbacher, Leopold 1961. Verkauft um dreissig Silberlinge. Apokryphen und Legenden um den Judasverrat. Schweizerisches Archiv für Volkskunde. 57, pp. 1-17.

Kretzenbacher, Leopold 1972. Zeugnis der stummen Kreatur. Zur Ikonographie eines Mirakels der Nikolaus von Tolentino. Legende. In Ennen, Edith und Wiegelmann, Günter (Hrsg.s). Festschrift für Matthias Zender. Studien zu Volkskultur, Sprache und Landesgeschichte. I. Bonn: Ludwig Röhrscheid, pp. 435-446.

K'urc'ikiże, C. (ed.) 1985. Nik'odimosis apok'rip'uli c'ignis K'art'uli versia. Tbilisi: Mecnierba.

Leach, Maria (ed.) 1949. Standard Dictionary of Folklore, Mythology, and Legend. New York: Funk and Wagnalls Company.

Le grande encyclopédie. Inventaire raisonné des sciences, des lettres et des artes. 2. Paris. Sine anno.

Lehmann, Paul 1929. Judas Ischarioth in der lateinischen Legendenüberlieferung des Mittelalters. Studi medievali, 2a serie, a. 2, Turin, pp. 289-346.

Lindström, B. (ed.) 1974. A late Middle English version of the Gospel of Nicodemus. Edited from British Museum Harley 149. Uppsala: Almquist \& Wiksell. [Acta Universitatis Upsaliensis, Studia Anglistica Upsaliensia, vol. 18.]

Madas, Edit 1989. Adatok az Érsekújvári Kódex sermoihoz. [Data to the sermos of the codex from Érsekújvár] Szelestei N. László (ed.). Tanulmányok a középkori magyarországi könyvkultúráról. Az OSzK-ban 1986. február 13-14-én rendezett konferencia elöadásai [Studies on the book culture in Medieval Hungary. Conference papers]. Budapest: OSzK, pp. 203-223.

Mailly, Anton von 1993. Leggende del Friuli e delle Alpi Giulie. Pubblicate con la collaborazione di Johannes Bolte. Edizione critica a cura di Milko Matičetov. Gorizia: Editrice Goriziana.

Marian, Simeon Florea 1904. Legendele Maicii Domnului. Studiu folkloristic. București: Edicțiunea Academiei Române, "Carol Göbl”.

McNamara, Martin 1975. The Apocrypha in the Irish Church. Dublin: Dublin Institute of Advanced Studies.

Mikos, Éva 2005. Szerelemdal ... Megjegyzések egy Csokonai-vers népszerüségéről, valamint társadalom- és müvelődéstörténeti kapcsolatairól a XIX. századi kalendáriumok alapján. [Love-songs ...Remarks on the popularity and social and cultural-historical relationships of a Csokonai's verse]. Gulyás, Judit \& Tóth, Arnold (eds.).Mindenes gyüjtemény. II. Folklorisztikai tanulmányok Küllös Imola tiszteletére [Artes Populares 23] [General collection II. Folkloristic studies in honour of Imola Külős]. Budapest: ELTE Folklore Tanszék, pp. 169-190.

Morris, R. 1874-93. Early English Text Society (EETS), Original Series, 7 vol.s.

Moser, Dietz-Rüdiger 1974. Die Saat im Acker der Gerechten. Zur Vorgeschichte und Sinndeutung der Kornfeldlegende. Österreichische Zeitschrift für Volkskunde Bd. 77, Neue Serie Bd. XXVIII, pp. 131-142. 
Mot. = Thompson 1966 .

Mussafia, Andrius bei 1869. Sitzungsberichte der Wiener Akademie, 63.

Nagy, Ilona 2001. Apokrif evangéliumok, népkönyvek, folklór [Apocryphal gospels, popular literature, folklore]. Budapest: L'Harmattan. [Szóhagyomány. Sorozatszerkesztő: Nagy Ilona] [Orality. Editor of the series Ilona Nagy].

Petzoldt, Leander 1977. Historische Sagen II. Ritter, Räuber und geistliche Herren. Hrsg. und erläutert von. München: C. H. Beck.

Piovanelli, Pierluigi 2003a. Exploring the Ethiopic Book of the Cock: An Apocryphal Passion Gospel from Late Antiquity. Harvard Theological Review 96:4, pp. 427-454.

Piovanelli, Pierluigi 2003b. Pre- and Post-Canonical Passion Stories. Apocrypha 14, pp. 99-128.

Piovanelli, Pierluigi 2006. The Book of the Cock and the Rediscovery of Ancient Jewish Christian Traditions in Fifth Century Palestine. Henderson, I. and Oegema, G. S. (eds.): The Changing Face of Judaism, Christianity and Other Greco-Roman Religions in Antiquity. Gütersloh: Gütersloher Verlagshaus, 318-332.

Puchner, Walter 1994. Zur Herkunft der mittelalterlichen Judaslegende. Fabula Bd. 35, Heft 1/2, pp. 305-309.

Scheidweiler, Felix 1990. Nikodemusevangelium. Pilatusakten und Höllenfahrt Christi. Hennecke, Edgar \& Schneemelcher, Wilhelm 1990: 395-423.

Santos Otero, Aurelio de 1981. Die handschriftliche Überlieferung der altslavischen Apokryphen. Vol. 2. Berlin: Walter de Gruyter, pp. 61-98.

Schneemelcher, Wilhelm 1959. Haupteinleitung.Hennecke, Edgar \& Schneemelcher, Wilhelm (Hrsg.s) 1959. Neutestamentliche Apokryphen in deutscher Übersetzung. I. Band. Evangelien. 3, völlig neubearb. Aufl., hrsg. von W. Schneemelcher. Tübingen: Verlag v. J. C. Mohr, pp. 40-51.

Szilády, Áron 1910. Sermones Dominicales. Két XV. századból származó magyar glosszás latin kódex. I. [Two Latin glossaries from the 15th century] Budapest: Magyar Tudományos Akadémia kiadása.

Thilo, J. C. 1823: Codex apocryphorum Novi Testamenti. Vol. 1. Leipzig: F. C. G. Vogel.

Thomson, Francis J. 1985. Apocrypha slavica. II. The Slavonic and East European Review 63, pp. 79-83.

Thompson, Stith 1966. Motif-Index of Folk Literature. A Classification of Narrative Elements in Folktales, Ballads, Myths, Fables, Mediaeval Romances, Exempla, Fabliaux, Jest-Books and Local Legends. Vol. 2. Bloomington: Indiana University Press.

Tischendorf, Constantin 1876. Evangelia Apocrypha. Adhibitis plurimis codicibus Graecis et Latinis maximam partem nunc primum consultis ineditorum copia insignibus collegit atque recensuit Constantinus de Tischendorf. Editio altera. Lipsiae: Hermann Mendelssohn.

Uther, Hans-Jörg 2004. The Types of International Folktales. A Classification and Bibliography. Based on the System of Antti Aarne and Stith Thompson. I-III. Folklore Fellows' Communications No. 284-286. Helsinki: Academia Scientiarum Fennica.

Tubach, Frederic C. 1969. Index Exemplorum. A Handbook of Medieval Religious Tales. Folklore Fellows' Communications. No. 204. Helsinki: Academia Scientiarum Fennica. 
Volf, György 1888. Régi magyar codexek: Érsekújuári codex. [Old Hungarian codices: The codex from Érsekújvár]. Nyelvemléktár IX. Budapest: Hornyánszky Viktor akadémiai könyvkereskedése.

Wimmer, Erich 1978. Bratenwunder. Ranke, Kurt (Hrsg). Enzyklopädie des Märchens. Handwörterbuch zur historischen und vergleichenden Erzählforschung. Bd. 2, Lief. 3/4. Berlin \& New York: Walter de Gruyter, pp. 684-688.

Worstbrock, Franz Josef 1983. Judaslegende. Stammler, Wolfgang \& Langosch, Karl (eds.). Die deutsche Literatur des Mittelalters: Verfasserlexikon, 4. 2nd ed. Veröffentlichungen der Kommission für Deutsche Literatur des Mittelalters der Bayerischen Akademie der Wissenschaften. Berlin \& New York: Walter de Gruyter, pp. 882-887.

Zowczak, Magdalena 2000. Biblia Ludowa: Interpretacje wątków biblijnych w kulturze ludowej. Seria Monografie Fundacji na rzecz Nauki Polskiej. Wrocław: Wydawnictwo. Funna. 